\title{
ОНОВЛЕННЯ ЗМІСТУ ТА ТЕХНОЛОГІЙ ФАХОВОЇ ПІДГОТОВКИ МАЙБУТНІХ МАГІСТРІВ ПСИХОЛОГІЇ В КОНТЕКСТІ ФОРМУВАННЯ ЇХ ГОТОВНОСТІ ДО ПРОФЕСІЙНОЇ ДІЯЛЬНОСТІ В НЕФОРМАЛЬНІЙ ОСВІТІ
}

У статті обгрунтовано дві важливі обставини, що сприяють формуванню готовності майбутніх
агістрів психології до профресійної діяльності в умовах неформальної освіти.
Рекомендовано застосування в навчально-виховному процесі спеціальності 053 Психологія двох
ранізаційно-педагогічних умов:

- використання технології змішаного навчання. Це забезпечує інтенсифікацію, персоналізацію, гнучкість, доступність та інтерактивність процесу підготовки майбутніх магістрів психології, а також зростання їх самостійності, адаптивності та мобільності у процесі навчання як критично важливих характеристик для їх професійної діяльності в умовах неформальної освіти. Крім цього, робота майбутніх магістрів психології з різноманітними електронними ресурсами, вебтехнологіями та онлайн-середовищем навчання забезпечила розвиток їх IКT-компетентності;

- оновлення змісту професійної підготовки магістрів психології забезпечує свідоме засвоєння магістрантами-психологами теоретичних та методичних аспектів їх діяльності в неформальній освіті, теоретичний базис для оволодіння сучасними та інноваційними технологіями освітньо-психологічноі діяльності, проектування та реалізацію на комерційній основі самостійно розроблених «стартапів» для суб'єктів неформальної освіти.

Показано, що «організаційно-педагогічні умови» виступають обставинами, які можна добирати відповідно до особливостей досліджуваного феномена, а за допомогою їх сукупності можна впливати на перебіг процесу підготовки майбутніх магістрів психології і сприяти його дієвості й успішності.

Із метою визначення комплексу організаційно-педагогічних умов, які є важливими для забезпечення ефрективності підготовки майбутніх магістрів психології до профресійної діяльності в умовах неформальної освіти проведено опитування експертів із цієї проблеми, в ролі яких виступили викладачі двох кафедр Класичного приватного університету: освіти та управління навчальним закладом та кафредри психології, які здійснюють професійну підготовку за цим напрямом.

Ключові слова: педагогічні умови, оновлення змісту, педагогічні технології, магістри психології, підготовка.

Постановка проблеми. Конструкт «організаційно-педагогічні умови» має передбачати сукупність обставин процесу підготовки, які стосуються його організації, форм, методів й змісту і є необхідними та достатніми для забезпечення ефективності підготовки майбутніх магістрів психології до професійної діяльності в умовах неформальної освіти. При цьому «організаційно-педагогічні умови» виступають обставинами, які можна добирати відповідно до особливостей досліджуваного феномена, а за допомогою їх сукупності можна впливати на перебіг процесу підготовки майбутніх магістрів психології і сприяти його дієвості й успішності.

Аналіз останніх досліджень і публікацій. Серед учених, які досить інтенсивно вивчали проблематику необхідних і достатніх педагогічних умов підготовки, варто виділити тих, що розробляли засоби розвитку їх професійної мотивації та ідентичності (І.А. Дружиніна, І.К. Старкова, С.П. Васильєв), ціннісних орієнтацій та цінніс- но-смислової сфрери (Т.Є. Тітова, Т.А. Вілюжаніна), соціально-професійної зрілості (Л.В. Логінова), креативного мислення (Н.М. Макаренко) механізмів адаптації до професійної діяльності в загальноосвітніх навчальних закладах (Л.Є. Бегеза), особистісних стратегій діяльності (Д.Д. Романовська), конкуренто-значущих якостей (Н.В. Ортікова), суб'єктності та самостійності (3.М. Адамська, I.В. Ендебера), стресостійкості як профресійно значущої якості (І.В. Походько), ініціативності (В.Ю. Шапран), професійного мислення (Т.Є. Гура), толерантності до невизначеності (С.О. Хілько) тощо.

Метою статті $€$ висвітлення авторської версії оновлення змісту та технологій фахової підготовки майбутніх магістрів психології в контексті формування їх готовності до професійної діяльності в неформальній освіті.

Виклад основного матеріалу. Із метою визначення комплексу організаційно-педагогічних умов, які $є$ важливими для забезпечення ефек- 
тивності підготовки майбутніх магістрів психології до професійної діяльності в умовах неформальної освіти, проведено опитування експертів із цієї проблеми, в ролі яких виступили викладачі двох кафедр: освіти та управління навчальним закладом та кафедри психології, які здійснюють професійну підготовку за цим напрямом.

Експертам пропонувалось вказати організаційно-педагогічні умови, які, на їхню думку, є найбільш ефективними для успішної підготовки майбутніх магістрів психології до професійної діяльності в умовах неформальної освіти.

Перелік визначених експертами в процесі опитування організаційно-педагогічних умов поданий у таблиці 1.

Отже, можна констатувати, що результативність процесу підготовки майбутніх магістрів психології залежить від великої кількості різноманітних організаційно-педагогічних умов, але кожна з цих умов справляє свій вплив на досліджуваний феномен.

На основі проведеного аналізу психолого-педагогічних джерел, експертного опитування та власного досвіду до комплексу організаційно-педагогічних умов, які $€$ необхідними та достатніми для забезпечення ефективної підготовки майбутніх магістрів психології до професійної діяльності в умовах неформальної освіти, нами було зараховано такі:

- оновлення змісту профресійної підготовки магістрів психології;

- використання технології змішаного навчання;

- використання інтерактивних технологій;
- використання проєктної технології;

- проходження польових (психологічних) практик.

Авторське бачення комплексу вибраних організаційно-педагогічних умов базується на їх визначенні як обставин організації, фрорм, методів та засобів, які забезпечують ефективність впровадження розробленої моделі й технології підготовки майбутніх магістрів психології до професійної діяльності в умовах неформальної освіти та успішне фрормування усіх структурних та змістових компонентів досліджуваної готовності.

Першою організаційно-педагогічною умовою формування досліджуваної готовності $\epsilon$ оновлення змісту професійної підготовки магістрів психології. При цьому зазначимо, що реалізація цієї умови спрямовувалась на фрормування переважно когнітивного та аксіологічного змістовних компонентів готовності майбутніх магістрів психології за всіма структурними складниками.

Для глибшого розуміння цієї умови з'ясуємо сутність концепту «зміст підготовки», проаналізувавши дослідження, присвячені проблемі профресійної підготовки майбутніх фрахівців у вищій школі.

Так, на думку В. Сітарова, змістом освіти у вищій школі $€$ сукупність наукової інфрормації, офрормленої у вигляді певної навчальної документації, яка володіє такими характеристиками, як необхідність, педагогічна обґрунтованість, логічність, послідовність тощо [1, с. 345]. Л. Хомич вважає, що підґрунтям змісту професійної підготовки у вищій школі має бути програмно цільовий підхід до плану-

\section{Узагальнені результати опитування експертів}

\begin{tabular}{|c|l|}
\hline № & $\begin{array}{l}\text { Організаційно-педагогічні умови підготовки майбутніх магістрів психології до професійної діяльності в умо- } \\
\text { вах неформальної освіти }\end{array}$ \\
\hline 1 & Формування позитивної мотивації магістрантів-психологів до педагогічної підготовки. \\
\hline 2 & Вдосконалення змісту профресійної підготовки. \\
\hline 3 & $\begin{array}{l}\text { Створення науково-методичного забезпечення з метою поглиблення теоретичних знань і удосконалення практичних } \\
\text { умінь роботи в неформальній освіті. }\end{array}$ \\
\hline 4 & Запровадження інноваційних форм і методів професійної підготовки. \\
\hline 5 & Забезпечення індивідуальної траєкторії підготовки для кожного магістранта. \\
\hline 6 & Застосування інноваційних технологій навчання. \\
\hline 7 & Забезпечення суб'єкт-суб’єктної взаємодії викладачів та магістрантів. \\
\hline 8 & Проектування змісту навчальних дисциплін з орієнтацією на неформальну освіту. \\
\hline 9 & Стимулювання рефлексії магістрантів-психологів у процесі навчання. \\
\hline 10 & Застосування інноваційних форм професійної підготовки майбутніх психологів у позанавчальній діяльності. \\
\hline 11 & Формування творчого мислення майбутніх магістрів психології. \\
\hline 12 & Використання тренінгових технологій. \\
\hline 13 & Поєднання традиційних і нетрадиційних форм організації навчального процесу. \\
\hline 14 & Формування ціннісно-смислових орієнтацій майбутніх магістрів психології. \\
\hline 15 & Використання інтерактивних методів навчання. \\
\hline 16 & Створення рефрлексивного середовища. \\
\hline
\end{tabular}


вання й управління освітнім процесом, який забезпечує синтез й інтеграцію усіх циклів дисциплін [10, с. 127-128]. Н. Манчинська, доповнюючи думки попередніх науковців, акцентує на необхідності формування такого циклу дисциплін та порядку їх вивчення, який зміг би забезпечити належну якість фахової підготовки магістрів [6, с. 27].

Проведений аналіз наукових джерел щодо сутності концепту «зміст підготовки» дає нам змогу сорормулювати загальні вимоги до вибору та структурування змісту підготовки майбутніх магістрів психології до професійної діяльності в умовах неформальної освіти. Зокрема, цей зміст має:

1) відповідати цільовим орієнтирам авторської концепції та моделі підготовки майбутніх магістрів психології;

2) розкривати особливості та напрями діяльності магістра психології в системі неформальної освіти, роль та функції, які виконує в цих умовах;

3) забезпечувати фрормування когнітивного змістового компоненту досліджуваної готовності для усіх структурних компонентів: педагогічного, підприємницького, технологічного, лідерського та емоційного інтелекту майбутнього магістра психології;

4) забезпечувати стартовий теоретичний потенціал для самостійного створення різноманітних освітньо-психологічних проектів («стартапів») неформальної освіти;

5) актуалізувати та сорормувати ціннісні орієнтації майбутнього магістра психології щодо професійної діяльності в умовах неформальної освіти.

Проаналізувавши зміст наявної програми підготовки магістрів психології, навчального плану, робочих навчальних програм, підручників, посібників, базуючись на вимогах Стандарту вищої освіти за спеціальністю «053. Психологія. Рівень освіти - магістр» і враховуючи соціальний запит на підготовку магістрів психології до професійної діяльності в умовах неформальної освіти, для реалізації цієї організаційно-педагогічної умови ми розробили навчальну програму дисципліни «Професійна діяльність магістра психології в умовах неформальної освіти».

Метою вивчення дисципліни «Профресійна діяльність магістра психології в умовах неформальної освіти» $є$ формування цілісного бачення майбутніх магістрів психології та концептуального розуміння власної діяльності в неформальній освіті. Зміст дисципліни розкривають такі теми: «Нормативно-правове забезпечення неформальної освіти»; «Функції та ролі магістра психології в умовах неформальної освіти»; «Магістр психології як підприємець неформальної освіти»; «Магістр психології як педагог неформальної освіти»; «Основні інструменти магістра психології в неформальній освіті»; «Традиційні та інноваційні технології в освіті та психології» та «Технологічна компетентність магістра психоло- гії». Опанування цієї дисципліни забезпечувало формування педагогічного та технологічного функціональних структурних компонентів та технологічного інструментального структурного компонента досліджуваної готовності.

Водночас для успішної реалізації авторського задуму, крім зазначеної дисципліни, нами розроблено нові спецкурси («Емоційний інтелект» та «Психологія лідерства») та введено нові теми (модулі) до окремих дисциплін професійної підготовки магістрів психології за спеціальністю «053. Психологія. Рівень освіти - магістр».

Так, у процесі вивчення спецкурсу «Емоційний інтелект» майбутні магістри психології ознайомлювалися з емоційною сферою людини, емоціями та емоційним підґрунтям міжособистісних відносин. Цей спецкурс спрямований на формування в магістрантів-психологів здатності розрізняти, контролювати та використовувати власні емоції й емоційні стани в подальшій професійній діяльності в неформальній освіті. Спецкурс забезпечував формування емоційного інтелекту як структурного компонента досліджуваної готовності.

Опанування спецкурсу «Психологія лідерства» забезпечувало спрямування магістрантів-психологів на усвідомлення важливостілідерськихздібностейдляуспішноїпрофесійної діяльності в умовах неформальної освіти. У межах цього спецкурсу відбувалося цілеспрямоване формування їх здатності до керування діяльності навчальної групи (особистості) в зазначених умовах. Спецкурс забезпечував формування лідерського структурного компонента досліджуваної готовності.

Новими модулями було доповнено навчальні дисципліни професійної підготовки:

- дисципліна «Педагогіка та психологія вищої школи» доповнена модулем «Педагогіка неформальної освіта», який спрямований на належну методичну підготовку магістрантів-психологів до педагогічної діяльності в неформальній освіті і забезпечує фрормування педагогічного структурного компонента досліджуваної готовності;

- дисципліна «Методика викладання психології» доповнена модулем «ІКТ у професійній діяльності психолога», що спрямований на формування базових знань та умінь із тих інформаційно-комп'ютерних технологій, які використовуються психологами в процесі реалізації своїх функціональних обов'язків, і забезпечує формування технологічного структурного компонента готовності.

Ця організаційно-педагогічна умова також передбачала оновлення змісту виробничої практики, яку пропонувалося реалізувати у вигляді польових (психологічних) практик, на яких магістрант-психолог мав змогу випробувати самостійно розроблені «стартапи» для професійної діяльності в умовах неформальної освіти. 
Таким чином, реалізація першої умови (оновлення змісту профресійної підготовки магістрів психології) забезпечувала свідоме засвоєння магістрантами-психологами теоретичних та методичних аспектів їх діяльності в неформальній освіті, теоретичний базис для оволодіння сучасними та інноваційними технологіями освітньо-психологічної діяльності, проектування та реалізацію на комерційній основі самостійно розроблених «стартапів» для суб'єктів неформальної освіти.

Другою організаційно-педагогічною умовою фрормування готовності майбутніх магістрів психології до професійної діяльності в умовах трансформації освіти є використання технології змішаного навчання, яка спрямована на забезпечення повноцінної очної та дистанційної взаємодії усіх суб'єктів підготовки.

Теоретичні та методичні аспекти використання технології змішаного навчання у процесі профресійної підготовки нині широко досліджуються сучасними українськими та зарубіжними науковцями, це зокрема: М. Бирка [1], С. Велединська, М. Дорофеєва [2], М. Іващенко, Т. Бикова [3], М. Кондакова, Е. Латипова [4], О. Кривонос, О. Коротун [5], В. Кухаренко, С. Березенська, К. Бугайчук [9], Я. Сікора [8] та інші.

Поняття "змішане навчання» (англ. blended learning) - це освітня технологія, за якою той, хто навчається, отримує навчальну інфоормацію самостійно за допомогою онлайн-ресурсів та має змогу очно зустрічатися з тим, хто викладає цей предмет.

На думку О. Кривонос і О. Коротун, ця технологія $€$ змішуванням елементів традиційної класно-урочної системи освіти та елементів інноваційної цифрової освіти [5, с. 20].

Незважаючи на простоту такого визначення, поєднання традиційного та інноваційного електронного навчання дають різноманітні види змішаного навчання.

М. Бирка [1], В. Кухаренко, С. Березенська та К. Бугайчук [9] розрізняють такі комбінації змішаного навчання:

1) змішування очного та дистанційного навчання;

2) змішування структурованого та неструктурованого навчання;

3) змішування електронних та паперових навчальних матеріалів;

4) змішування індивідуальної та групової роботи;

5) змішування роботи та навчання.

У контексті реалізації цієї умови доцільно виокремити й численні переваги технології змішаного навчання.

Так, на думку М. Кондакової та Е. Латипової, зазначена технологія характеризується такими перевагами:
- гнучкість та доступність, які дають змогу врахувати індивідуальні освітні потреби кожного студента, а також забезпечити індивідуальний режим навчання;

- інтерактивність та суб'єкт-суб'єктна взаємодія між викладачем та студентом, яка забезпечує перехід від трансляції навчальної інформації до самостійного конструювання знань студентами;

- персоналізація процесу навчання, адже за цією технологією кожен студент може самостійно визначати цілі навчання та способи їх досягнення відповідно до власних освітніх потреб, інтересів та здібностей [4, с. 60].

В. Кухаренко, С. Березенська та К. Бугайчук серед переваг, які надає технологія змішаного навчання, також виокремлюють підвищення мотивації тих, хто навчається, підвищення ефективності використання часу, забезпечення акценту на поглибленому вивченні дисципліни, полегшення процесу діагностики результатів навчання, фрормування навичок роботи в команді, економію коштів шляхом скорочення кількості поїздок на навчання та ін. [9, с. 56].

У контексті реалізації другої організаційно-педагогічної умови доцільно також обрати модель змішаного навчання, для чого необхідно визначити її структурні та змістові характеристики.

Так, О. Кривонос та О. Коротун у моделі змішаного навчання виділяють такі елементи: лекційні, семінарські та практичні заняття, завдання для самостійної роботи; навчально-методичні матеріали (підручники, посібники, методичні вказівки); засоби онлайн-спілкування (чат, фрорум, e-mail); віртуальна кімната, мультимедійні матеріали (аудіо-, відеолекції) та симуляції [5, с. 20]. Зазначимо, що таке бачення радше можна зарахувати до моделі дистанційного навчання, адже воно не відбиває основну характеристику змішаного навчання - наявність очної взаємодії між студентами та викладами.

У цьому контексті слушною є думка М. Бирки, який у своєму дослідженні в процесі реалізації технології змішаного навчання пропонує акцентувати на таких характеристиках, як спосіб доставки змісту навчання, діяльність того, хто навчається, формат подання навчальних матеріалів та компетентностях, які необхідні для навчання [1, с. 223].

Тому для успішної реалізації цієї умови в процесі підготовки майбутніх магістрів психології до професійної діяльності в умовах неформальної освіти нами обрано модель змішаного навчання «Online Driven», яка передбачає використання електронних ресурсів для опанування програми навчальної дисципліни, періодичні очні консультації з викладачем для обговорення труднощів, а також проведення очного заліку (екзамену). які $\epsilon$ обов'язковими (Я. Сікора) [8, с. 237-238]. 
У процесі реалізації цієї умови нами враховано, що, впроваджуючи технологію змішаного навчання у підготовку майбутніх магістрів психології, не доцільно переводити всі лекції в електронний формат, адже, крім подання теоретичних відомостей, кожна лекція має розвивати інтерес до навчання та формувати основу для подальшої самостійної роботи, що можна забезпечити тільки очною взаємодією студентів та викладачів. Також із метою спонукання магістрантів-психологів до активного самостійного опанування лекцій їх матеріал був викладений у форматі певної проблеми (проблемне подання), що забезпечувало самостійний пошук інформації, самостійне формулювання висновків та узагальнень із певної проблеми.

Водночас реалізація технології змішаного навчання в процесі підготовки майбутніх магістрів психології передбачає й використання інтерактивних технологій навчання, які будуть детальніше розглянуті нами в наступній умові.

У процесі реалізації цієї умови окрему увагу ми приділили організації електронного спілкування між магістрантами-психологами та викладачами, яке проводилося за допомогою сучасних інфоормаційно-комп'ютерних технологій (IКТ). Зокрема, нами використано технології синхронного (онлайн) та асинхронного (офрлайн) спілкування. Такими технологіями онлайн-спілкування (в режимі реального часу) були чат, месенджер та онлайн-сервіси, а асинхронними - електронна пошта та форум.

Для забезпечення групової взаємодії в режимі реального часу нами було використано технологію вебінар (М. Іващенко, Т. Бикова) [3, с. 223], яка $є$ різновидом вебконсреренції, що дає змогу створити віртуальну навчальну «аудиторію», що об'єднує всіх учасників: і магістрантів-психологів, і викладачів. Ця технологія уможливлює у процесі професійної підготовки майбутніх магістрів психології проведення в онлайн-режимі лекційних, семінарських і практичних занять 3 одночасним використанням електронних матеріалів та чату. Вебінар реалізується за допомогою спеціалізованих вебсервісів, найвідомішими з яких $€$ Wizlq, BigBlueButton та Videoleti.

Висновки і пропозиції. Рекомендовано застосування в навчально-виховному процесі спеціальності 053 Психологія двох представлених організаційно-педагогічних умов, а саме:

1) використання технології змішаного навчання. Це забезпечує інтенсифікацію, персоналізацію, гнучкість, доступність та інтерактивність процесу підготовки майбутніх магістрів психології, а також зростання їх самостійності, адаптивності та мобільності у процесі навчання як критично важливих характеристик для їх профресійної діяльності в умовах неформальної освіти. Крім цього, робота майбутніх магістрів психології з різноманітними електронними ресурсами, вебтехнологіями та онлайн-середовищем навчання забезпечило розвиток їх IКТ-компетентності;

2) оновлення змісту професійної підготовки магістрів психології забезпечує свідоме засвоєння магістрантами-психологами теоретичних та методичних аспектів їх діяльності в неформальній освіті, теоретичний базис для оволодіння сучасними та інноваційними технологіями освітньо-психологічної діяльності, проєктування та реалізацію на комерційній основі самостійно розроблених «стартапів» для суб'єктів неформальної освіти.

\section{Список використаної літератури:}

1. Byrka M.F. Blended learning strategy in teacher training programs. Information Technologies and Learning Tools. 2017. Vol. 62. No 6. Pp. 216-224. URL: https://journal.iitta.gov.ua/index.php/ittl/ article/view/1802/1277.

2. Велединская С.Б.,ДорофееваМ.Ю.Смешанное обучение: секреты эффрективности. Высшее образование сегодня. 2014. № 8. С. 8-13.

3. Іващенко М.В., Бикова Т.Б. Особливості використання елементів змішаного навчання в процесі викладання навчальних дисциплін у закладах вищої освіти. Физико-математическое образование. 2018. № 1 (15). С. 221-226. doi:10.31110/2413-1571-2018-015-1-041.

4. Кондакова М.Л., Латыпова Е.В. Смешанное обучение : ведущие образовательные технологии современности. Вестник образования. 2013. № 9 (2759). С. 54-64.

5. Кривонос О., Коротун О. Змішане навчання як основа формування ІКТ-компетентності вчителя. Наукові записки [Кіровоградського державного педагогічного університету імені Володимира Винниченка]. Серія : Проблеми методики фрізико-математичної і технологічної освіти. 2015. Вип. 8(2). С. 1923.

6. Манчинська Н. І. Педагогічна освіта магістрантів вищих навчальних закладів непедагогічного профрілю : монографрія / за ред. С.О. Сисоєвої. Львів : ЛьвДУВС, 2013. 416 с.

7. Ситаров В.А. Дидактика. Москва : Академия, 2002. $368 \mathrm{C}$.

8. Сікора Я. Реалізація змішаного навчання у вищому навчальному закладі. Науковий вісник Ужгородського національного університету. Серія : Педагогіка. Соціальна робота. 2016. Вип. 2. С. 236-239.

9. Теорія та практика змішаного навчання : монографрія / [Кухаренко В.М., Березенська С.М., Бугайчук К.Л. та ін.] ; за ред. В.М. Кухаренка. Харків : Міськдрук, НТУ ХПІ, 2016. 284 с.

10.Хомич Л.О. Професійно педагогічна підготовка вчителя початкових класів: теорія і практика : монографрія. Київ : Магістр S, 1998. 200 с. 
Ponomarenko $\mathrm{O}$. The content and technologies updates in professional training of future masters of psychology in the context of formation of their readiness for the professional activity in non-formal education

The article lays the foundation for two important circumstances that contribute to the formation of the readiness of future masters of psychology for professional activity in the context of non-formal education.

It is recommended to use the two presented organizational and pedagogical conditions in the educational process in the specialty 053 Psychology. They are the following:

- use of blended learning technology to ensure the intensification, personalization, flexibility, accessibility and interactivity of the training process of future masters of psychology, as well as the enhancement of their independence, adaptability and mobility in the learning process, as critical characteristics for their professional activity in the context of non-formal education. In addition, the work of future masters of psychology with a variety of electronic resources, web technologies and online learning environment has enabled the development of their informational and communicative competence;

- updating the content of professional training of masters of psychology provides conscious mastering by undergraduate psychologists of theoretical and methodological aspects of their activities in non-formal education, theoretical basis for mastering modern and innovative technologies of educational and psychological activities, design and implementation of commercially developed "startups" for subjects of non-formal education.

It is shown that "organizational and pedagogical conditions" are circumstances that can be selected according to the characteristics of the phenomenon under study, and with their combination can influence the process of training future masters of psychology and contribute to its effectiveness and success.

In order to determine the set of organizational and pedagogical conditions which are essential to ensure the effectiveness of preparation of future masters of psychology for professional activities in non-formal education, there has been a survey of experts on this issue. The expert panel is the group of teachers of two departments of Classical Private University: education and management and psychology departments who provide professional training in this area.

Key words: pedagogical conditions, content updating, pedagogical technologies, masters of psychology, training. 